\title{
Entrevista com Rieli Franciscato, sertanista e indigenista, Coordenador da Frente de Proteção Etnoambiental Uru-Eu-Wau-Wau
}

\author{
Interview awarded by Rieli Franciscato, sertanista and \\ indigenista, Coordinator of the Uru-Eu-Wau-Wau \\ Ethno-Environmental Protection Front \\ Apresentação por Ana Suelly Arruda Câmara Cabral
}

\begin{abstract}
Rieli Franciscato dialoga com Antenor Vaz sobre a formação de indigenistas para o trabalho de campo com povos indígenas isolados, tendo como referência a sua própria história. Fala da política do não contato implantada na segunda metade da década de 1980, mas que só se consolida com o desenvolvimento de uma metodologia inovadora para o estudo de referências de povos indígenas isolados. Rieli Franciscato e Antenor Vaz explicam que essa metodologia consiste na identificação, localização, registro e mapeamento de referências desses povos, as quais são indispensáveis para subsidiar a definição territorial dos mesmos. Rieli fala de como se tornou um sertanista, de sua vivência com os Tuparí e com outros povos de Rondônia. Fala também da importância do conhecimento pelos sertanistas/indigenistas de línguas indígenas nas situações de contatos eventuais com povos em isolamento voluntário. A entrevista, concedida por Rieli Franciscato a Ana Suelly A. C. Cabral, Antenor Vaz e Ariel Pheula do Couto e Silva, nos dias 5 e 6 de abril de 2015, no Laboratório de Línguas e Literaturas Indígenas / UnB é uma contribuição para a história do indigenismo e das políticas públicas voltadas para a proteção de índios isolados e de recente contato no Brasil.
\end{abstract}




\section{Entrevista / Interview: Rieli Franciscato}

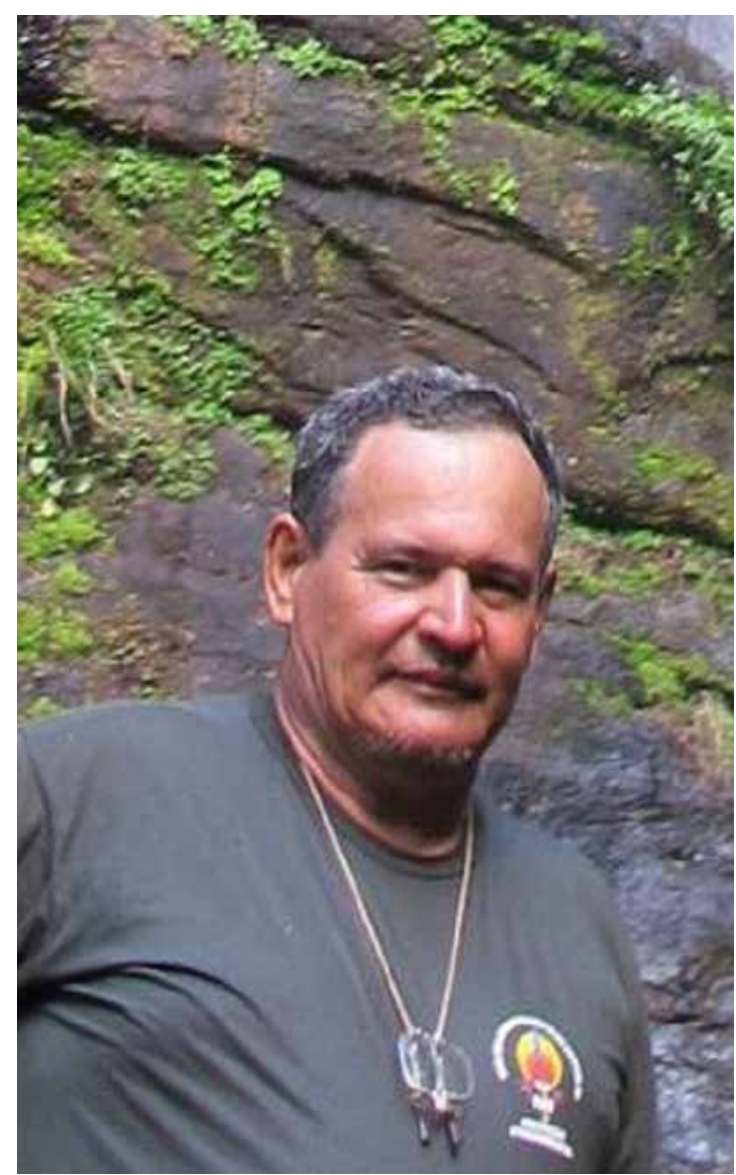

Antenor Vaz: Sobre a minha participação nos trabalhos de localização dos índios isolados da Reserva Biológica do Guaporé, e na Coordenação de Estudos Indigenistas CEI, na FUNAI, sempre me preocupava em criar condições de continuidade dos trabalhos. $\mathrm{Na} C E I$, promovi encontros com o objetivo de instrumentalizar as pessoas, principalmente no que diz respeito ao "escutar os índios"; a ideia era proporcionar a essas pessoas a apreensão de instrumentos conceituais que os permitissem interpretar o mundo indígena. Bom, mal ou ruim, o próprio Estado brasileiro, através de suas instituições, tinha um espaço para formar pessoas para o trabalho com os índios, mesmo sendo a política do Estado a de integração ou não.

A questão que se coloca hoje é: "O que se está formando hoje em dia? Quem são as pessoas que estão entrando para trabalhar com a questão indigena? Rieli, você, que trabalha em área, como você descreve essa realidade?"

Rieli: É justamente essa a nossa angústia. Não está ficando ninguém. A grande maioria desse novo pessoal que entrou na FUNAI por concurso, por exemplo, auxiliares de indigenismo, já não está mais em campo. O campo está esvaziado. Ficaram apenas aqueles que possuem o nível médio de estudos, os agentes de indigenismo e os indigenistas especializados. Então, há falta de pessoas para o trabalho em campo, e não há quem tenha vontade de ficar em campo, nem há 
preparação de pessoal para esse fim. Isso também porque, com a reestruturação ocorrida em 2009, o objetivo hoje não é mais campo, só se permanece temporariamente em área. Acabaram com os postos indígenas, a partir de onde se fazia o antigo trabalho de campo. Restaram as Coordenações Técnicas Locais - CTLs, que se configuram em um modelo de trabalho na cidade, com entradas temporárias nas aldeias, e que não funciona, nós sabemos que não funcionam. Mas não conseguiram nem mesmo implantar esse modelo, trazendo-as para a cidade. Atualmente, não há mais instrumento para que se possa dispor de pessoas para trabalhar em campo, e aqueles que ficavam em campo, que eram os chefes de posto, foram transformados em chefes de CTLs, atuando na cidade.

Antenor Vaz: Mas o Estado está lá presente, por meio das escolas e dos postos de saúde?

Rieli: É, só. E cada um fazendo a sua política, da forma que entende e isoladamente.

Antenor Vaz: A FUNAI não está mais presente?

Rieli: Não. Nos Uru-Eu-Wau-Wau, permanece uma das CTLs, mas por insistência nossa, pois era para ter sido também extinta da Terra Indígena e levada pra cidade. E não há nenhuma preparação das pessoas; a única ambientação ocorrida dos novos concursados foi uma preparação teórica, realizada aqui em Brasília. Foi em um encontro realizado no ano passado (2014) lá, ou seja, um dia de campo na nossa avaliação. A gente ainda chegou a comentar sobre isso, e, em nossa avaliação, aquele tipo de trabalho deveria ser uma experiência de ambientação dos novos servidores da FUNAI, em campo, por meio de um contato direto com a realidade; primeiro uma vivência nas aldeias, mesmo para aqueles que atuariam parcialmente em área.

Antenor Vaz: $E$ assim. Eu acompanhei um pouco essa ambientação dos servidores novos da FUNAI, que ocorreu aqui em Brasília, tanto a sua concepção quanto a sua execução. No fundo, no fundo, não foi uma ambientação. O que ocorreu, na prática, foi um reflexo do processo de ruptura que estava sendo vivenciado pela FUNAI. Era um novo modelo que estava sendo instituído na instituição. Um modelo gerencial. A FUNAI estava vivendo um processo de reestruturação institucional, que chegava até às pontas dessa forma, tirando, acabando com os postos e trazendo todos os indigenistas que estavam lá, na ponta, para cidade. E você tinha uma reação tanto dos antigos da FUNAI como das pessoas que tinham vivenciado a FUNAI em outras épocas. E havia os novatos que acabavam de entrar na FUNAI. Esses novatos ficaram em campo de batalha. Ficaram entre apoiar essa nova forma ou apoiar as pessoas que eram contra essa nova forma. E, na verdade, a ambientação funcionou para fazer com que esses servidores apoiassem a reestruturação. Mas, então, se coloca a questão da maneira de trabalhar com índios que, se é certa ou errada, 
se é boa ou se é ruim, foi construída na história do Brasil uma maneira que até se chama de indigenismo, de indigenista. Foi durante várias conversas com Ana Suelly que ela sempre colocava a importância de se registrar essa forma de trabalhar com os indios. Dai surgiu a ideia de publicarmos na Revista Brasileira em Linguística Antropológica - RBLA, questões referentes a: "quem são os indigenistas", "como é que se trabalha com indio", entre outras. Foi a partir dessa preocupação que pensamos em convidar pessoas que têm trajetória no indigenismo brasileiro, dai estamos iniciando com você Rieli. A ideia é possibilitar o registro para oferecer aos que têm interesse em saber como é que se desenvolvia um trabalho indigenista, que encontre nesta revista uma referência sobre isso. Pensamos também em convidar Meireles ${ }^{1}$, para falar sobre a sua trajetória. Tínhamos a perspectiva de que o Wellington pudesse contribuir com as muitas coisas que ele tem escritas em seus diários de campo. Pensamos também em convidar o Marcelo ${ }^{2}$ o Jair $^{3}$ e o Altair $^{4}$ e alguém da nova geração, no caso, o Fabrício ${ }^{5}$ ? Mas, como a Ana colocou agora há pouco, não há projeto para financiar essa proposta, custeando a vinda de todos para serem entrevistados. Então, nesse sentido, antes de a gente chegar na questão indígena, a gente gostaria de saber um pouco de você, de sua história, de sua trajetória.

Rieli: De como ingressei na FUNAI?

Antenor Vaz: Antes disso.

Ana Suelly: De você, de sua história de vida. O que levou você a ser um sertanista, o que antecede o seu engajamento com a questão indigena e com os indios isolados e de recente contato. Um pouco de sua história de vida, antes disso.

Rieli: Bom, eu nasci no Paraná. Hoje estou com 50 anos de idade. Fui para Rondônia, passando pelo Mato Grosso, tendo saído do Paraná com sete anos. Passei um tempo no Mato Grosso e depois fui para Rondônia, em 1985.

Antenor Vaz: Com oito anos, você foi para Mato Grosso...

Rieli: É, com sete para oito anos fui para Mato Grosso. Em 1985, a gente se mudou para Rondônia. Como tantos outros, que iam naquela busca de terra em lugares

\footnotetext{
${ }^{1}$ José Carlos dos Reis Meirelles, sertanista e indigenista.

${ }^{2}$ Marcelo dos Santos, sertanista e indigenista.

${ }^{3}$ Jair Catabriga, sertanista e indigenista, responsável pela Frenete de Proteção Etnoambiental Madeirinha.

${ }^{4}$ Altair José Algayer, sertanista e indigenista, responsável pela Frente de Proteção Etnoambiental Omerê.

${ }^{5}$ Fabrício Ferreira Amorim, indigenista, Coordenador da Coordenação de Proteção e Localização de Índios Isolados (COPLII/CGIIRC/Funai).
} 
novos, para formar suas propriedades, enfim, para trabalhar com agricultura. Toda a minha família, tem tradição de agricultor mesmo. Família agricultora. E lá, em Rondônia, a gente adquiriu uma terra; compramos uma terra vizinha à uma Terra Indígena, que é a Terra Indígena Rio Branco. E eu, de índio, sabia aquilo que aprendemos na escola! Não sabia nada, ou seja, sabia que o índio era sujo e que comia comidas diferentes, estranhas. Lá era, assim, um local novo, difícil; o acesso para chegar lá era difícil. Os índios, por sua vez, tinham uma dificuldade maior ainda, porque o acesso deles não era por Alta Floresta, era por Guajará-Mirim, e era feito duas vezes no ano. Só no início, ou seja, quando o rio se elevava e quando estava próximo de baixar, era quando eles se abasteciam novamente, tiravam a produção deles, pelo rio, de borracha e castanha. Ainda naquela época, o local era muito distante de Guajará-Mirim. Os índios tinham um motor pequeno de barco, um MER13HP, e a viagem durava 30 dias para ir lá em Guajará e voltar. Eles precisavam de muitas coisas e acabavam por procurar a gente, que era o vizinho mais próximo. A gente, um pouco receosa, foi, aos poucos, estabelecendo uma relação com aquela comunidade. A gente ficava até um pouco preocupada, porque diziam que o índio roubava muito, aquela coisa preconceituosa mesmo com o índio, não é? E aí nossa relação foi se construindo, e fomos percebendo que não tinha nada a ver com o que ouvíamos, ou seja, era um pessoal respeitoso, que respeitava muito a gente; e foi se estabelecendo a nossa relação, foi se consolidando. Era uma época, assim, de muita malária, e aquele abandono, assim, pela FUNAI, já naquela época. Passávamos por um momento, em que, por meio da Administração Regional de Porto Velho, era dada assistência ali; já não era mais por meio de Guajará-Mirim. Foi nessa transição, passando da Administração Regional de Guajará-Mirim para Porto Velho, que começaram a aparecer aqueles primeiros carreadores - estradas que chegavam próximo à Terra Indígena, ou chegavam até o Rio Branco -, que davam acesso à Terra Indígena. E aí, desse momento em diante, eles acabaram ficando muito abandonados, né, e aí eles recorrendo à gente. Então veio a história da venda da madeira ali na região de Alta Floresta, que é um local muito rico em madeira, assim como na Terra Indígena. E essa exploração foi indo e foi chegando até na Terra Indígena. Começaram, então, os roubos, os furtos de madeira na Terra Indígena. E aí, a gente, na época, participou de um trabalho com os índios. Por fim, a gente já tinha uma amizade com eles e falava para eles: “-- Olha, o pessoal tá entrando lá na terra de vocês em tal canto.” Então eles comunicavam aos servidores da FUNAI, que diziam a eles que não era verdade que houvesse alguém tirando madeira. E só depois, mais tarde, eu fui compreender, qual era a razão disso. É que havia envolvimento dos próprios servidores da FUNAI com o roubo das madeiras. Houve uma vez em que me aborreci e disse, "-- Vocês querem ir lá ver? Eu vou mostrar para vocês!’. E a gente foi lá fazer uma ação. Antenor até sabe das histórias dos tratores...

Antenor Vaz: Uhum... 
Rieli: Na época, estava lá. Andamos lá e depois de três dias, chegamos no local onde estavam as máquinas trabalhando. Éramos eu e mais oito índios, dentre os quais, indígenas Makuráp e Tuparí. E, assim, já estava bem conversado que era uma situação, ou seja, que podia ser uma situação perigosa. Naquele tempo, em Rondônia, as situações como essa eram resolvidas meio assim, na forma meia bruta. Os índios estavam bem conscientes da situação que a gente poderia enfrentar, situação bem difícil. Sabiam também o que poderia ocorrer se pegássemos alguém lá dentro. $\mathrm{O}$ cacique era o seu Anísio, então eu disse para ele que a gente ia levar esses equipamentos para o posto indígena, ou seja, para a Terra Indígena, para a aldeia. Ele então disse que estava bom. Pegamos, então, esse maquinário lá, alguns tratores, dois tratores e um jipe, e botamos os madeireiro para correr da Terra Indígena. Levamos, então, esses equipamentos para o posto, que ficava a uns 20 quilômetros, e a gente parando mata por dentro, levando uma esteira e um trator. Eu levava um pedaço a esteira, e como eles não dirigiam, levava um pedaço a esteira, voltava, pegava o trator, levava até um trecho, até onde alcançava a esteira, e levando o jipe guinchado. No primeiro dia, o jipe já se desmanchou pelo meio da mata, porque era muita serra, e não tinha como fazer. Aí continuamos, e os índios dando segurança. Um grupo de índios dando segurança atrás, porque o pessoal podia vir atrás para fazer alguma represália, e mais dois índios dando a direção, na frente. A gente gastou nove dias para chegar no posto, varando essa mata. E, a partir daí, os índios começaram a pedir que eu fosse trabalhar com eles. Eu apenas começava e já estavam gostando do trabalho, porque a gente sempre gostou de mato, a gente foi criada na mata, sempre teve essa familiaridade com a mata, assim..., essa facilidade com o ambiente,... ou seja, o ambiente com que a gente é acostumado. E começamos a achar interessante aquele trabalho, a achar que os índios não eram aquilo que ouvíamos sobre eles, que a gente tinha informação errada acerca deles. Então fomos conhecendo tudo ali. Eu tive várias dificuldades, lá, naquele momento. É que não era também interesse para a FUNAI que eu ficasse ali, porque estava atrapalhando, não propriamente a FUNAI, mas os servidores que estavam envolvidos naquela questão de roubo de madeira. Eram eles que não queriam que eu continuasse trabalhando ali. E, nesse momento, foi quando surgia o início dos trabalhos com os índios isolados da Reserva Biológica do Guaporé.

Antenor Vaz: Só um minutinho! Antes de entrarmos nesse ponto, o que é que você percebeu quando você passou a ter essa relação com os índios; porque você disse que já tinha relação com o mato, mas e a relação dos índios com o mato era igual à relação que você tinha com o mato?

Rieli: Era a mesma, assim..., aquela identificação com a mata, mas a gente aprendia muito com eles.

Antenor Vaz: O quê, por exemplo? 
Rieli: Ah!... tudo, não é? A questão de orientação, (...) a gente caçava naquele tempo, eu também era um caçador, vou lá pegar uma paquinha na mata, ou seja, uma coisa assim, para consumo mesmo. E os índios.... com os índios a gente aprendia todas essas técnicas de assoviar um bicho, de chamar uma anta. Antes eu sabia correr atrás de uma anta, e com eles a gente aprende a fazer a anta vir e chegar até onde a gente está, e não a gente ir atrás da anta, assim, essas coisas. A forma de lidar com a mata, a gente aprendeu muito com eles também, né? É bom, então, nisso surge esse trabalho lá.

\section{Antenr Vaz: Como é que souberam de você?}

Rieli: Pelos próprios servidores da FUNAI. A equipe estava chegando na região e procurou o núcleo em Ji-paraná. Então a FUNAI me indicou. Falou que tinha uma pessoa lá, próxima, que eles conheciam, e que conhecia bem a mata, que conhecia bem a região. Daí foram lá para ver se eu queria acompanhar eles na expedição.

\section{Antenor Vaz: Foi o Assis ${ }^{6}$ ?}

Rieli: Foi o Assis. É bom registrar, que foi um ano depois disso que mudou a política, aquela política de contato, para a política com a prerrogativa do ano contato. Iniciava-se, então, a nova política. Ou seja, foi criada em 1987, mas o trabalho lá foi iniciado já em finalzinho de 1988.

Antenor Vaz: Eles chegaram a ir lá, na fazenda dos seus pais, foi isso?

Rieli: É, eles chagaram lá em casa, lá na fazenda, o Assis, o Vicente, o Fernando.

Antenor Vaz: O Vicente era chefe de posto, não era?

Rieli: Era o chefe de posto do Cajuí na Terra Indígena Rio Branco. Então, eles foram lá, e disseram assim, "Você quer ir participar de uma expedição e tal, ir lá na... Você conhece bem a região..., e depois que você retornar, depois que a gente fizer o trabalho lá, daí você retorna para Terra Indígena Rio Branco, ou seja, para continuar trabalhando com os índios aqui." Respondi que, assim, estava ótimo. Aí a gente fez a primeira expedição, (...) descendo o rio Branco mesmo, e lá da aldeia... do Morro Pelado, a gente fez a primeira caminhada.

Antenor Vaz: Entrando no Morro Pelado em direção à reserva Biológica do Guaporé, onde se supunha ter os Isolados?

Rieli: É. Entrando no Morro Pelado e pegando o limite sul da Terra Indígena; e em um certo trecho, a gente saiu para chegar na serra do João Antunes. E aí, já no quinto dia, a gente sem encontrar com os índios. E, assim, começamos a encontrar vestígio, mais velho e, de repente, sem encontrar vestígio novo, já nos encontramos com os índios. Aí, a gente estava já há uns cinco dias caminhado,

${ }^{6}$ Francisco Assis Costa. 
e não tinha encontrado nenhum igarapé com água e nem um local com água. A gente bebia água só de cipó, então, não tinha mais condições de a expedição continuar. Porque naquele rio ali, naquela região baixa, todos os igarapés secam. Certo que ali onde estavam os índios tinha água, só que como os índios estavam ali, não se podia ir lá procurar água, porque certamente era onde estava o acampamento deles

Antenor Vaz: E como foi? Viram os índios?

Rieli: Chegaram a ser avistados pelo Biguá, que era o índio Tuparí que estava na frente cortando. Ele chegou a avistar dois índios.

Antenor Vaz: Eles viram? Os índios viram?

Rieli: Os índios viram. Mas a gente que estava atrás, não chegou a vê-los. Havia muito vestígio com tudo deles quebrado.

Antenor Vaz: Isso no pé da Serra João Antunes?

Rieli: Não, era bem antes, era saindo do Surubim, do igarapé Surubim.

Ana Suelly: E que índios eram?

Rieli: Eram os índios isolados do Massaco, da atual Terra Indígena Massaco. Aí retornamos...

Antenor Vaz: $O$ Rieli, só para esclarecer, foi convidado para integrar a equipe, a fazer parte da Equipe de Localização dos Índios Isolados da Reserva Biológica do Guaporé, que era chamada assim, não era?

Rieli: Isso.

Antenor Vaz: Era a equipe de localização. E quem era o coordenador da equipe?

Rieli: Era o Assis, Assis Costa, que ainda está vivo e que mora em Cuiabá.

Antenor Vaz: E Rieli topou, mas com a promessa de que depois que ele fizesse algumas expedições, ele voltava para trabalhar na Terra Indigena Rio Branco, porque existia um pedido dos índios da Rio Branco para que ele fosse contratado pela FUNAI para trabalhar com eles.

Rieli: Bom, aí não dava para prosseguir, porque a gente chegou naquela situação em que estávamos sem água, e não dava para ficar procurando água, porque era uma região que os índios estavam ocupando. Com certeza, no lugar deles tinha água. Aí a expedição foi recuado. Voltamos, então, e aí a gente entrou por uma outra região, pelo oeste e, em seguida, pelo leste, que dava na linha 95 (estrada construída por madeireiros e grileiros no interior da REBIO Guaporé, aquela estrada que levava até lá dentro da Reserva Biológica.

Antenor Vaz: Bom, vocês, então, fizeram esse percurso de carro? 
Rieli: Fizemos esse percurso de carro e adentramos a Reserva Biológica, 95 quilômetros de carro, por cima de estrada de madeireiro, em pleno território dos isolados, do grupo isolado de lá. E, assim, sempre naquela..., buscando informações com as pessoas dali. Diziam, "Não, aqui não tem índio", "Ninguém vê índio aqui", "Não tem vestígio, né?". Mas a estrada era aberta em cima de um varadouro dos índios. Aí, chegamos lá, montamos um acampamento novo, no último ponto em que chegava o carreador (estrada por onde os madeireiros escoam as madeiras) do madeireiro. Dali fomos fazer a expedição pela entrada da serra, que eles chamam Serra da Bundinha. E ali encontramos, naquela expedição, vestígio um pouco mais antigo, vestígio de um ano, dois tapiris (acampamentos indígenas). Aí chega o período chuvoso, época em que os madeireiro saem de dentro da Reserva Biológica. Foi no ano seguinte que o Antenor chegou lá e que a gente fez um levantamento melhor. Segundo nosso levantamento, tinha cerca de umas 40 famílias (de agricultores) morando dentro da Reserva Biológica, e umas 700 posses demarcadas (por grileiros) dentro dessa REBIO, onde estavam os índios, ou seja, os índios estavam acuados no último cantinho ainda de mata virgem que restava. Bom, aí chegou o período chuvoso, e os madeireiro saem porque não dá para explorar madeira nessa época, e a gente ficou com o acampamento lá dentro. Sai o pessoal para folga, ficando eu e um outro servidor que era o Raimundo (irmão do Assis). Aí os índios aparecem, ou seja, a gente não os viu, mas fincaram estrepe até quase dentro do nosso acampamento. $\mathrm{O}$ objetivos dos índio isolados é que furássemos nossos pés. Era uma atitude de nos expulsar dali. Eles estavam demarcando o território deles.

Antenor Vaz: Naquele antigo, o primeiro acampamento da Equipe de localização?

Rieli: É... a poucos metros do acampamento, coisa de uns 50 metros do acampamento, eles botaram estrepe.

Ana Suelly: O que é estrepe?

Rieli: Estrepe é uma armadilha que eles fazem, colocando-as em picadas.

Antenor Vaz: Eles fazem um espeto de madeira pontiagudo, fininho, com madeira dura de cerne para enterrar no chão e as pessoas pisarem neles e se ferirem.

Rieli: Aí, né, se inicia...

Antenor Vaz: Rieli, só um minutinho! É nesse periodo aí que você está falando, que vocês ficaram ilhados dentro da Reserva Biológica, não foi isso? Porque começou a chover muito, as estradas ficam intransitáveis, tinha região que alagava mais de 10, e até 20 quilômetros, e não se passava carro. Essa estrada cruzava vários igarapés e esses igarapés tinham as pontes improvisadas, nas 
quais eles faziam os bueiros. Nas chuvas, nas enxurradas, a água carregava tudo, então, além de estar tudo alagado, você não tinha a menor condição de transitar. Mas nesse periodo que você está falando, vocês primeiro montaram um acampamento no local em que os índios vieram e chegaram a colocar estrepe, quase dentro do barraco, não é? Porque parece que o barraco estava no meio de um dos caminhos deles, não é isso?

Rieli: Isso.

Antenor Vaz: Mas nesse periodo, não foi um periodo em que vocês já deixaram uns brindes pendurados?

Rieli: Foi. A gente fez uma primeira expedição para a Serra da Bundinha, que a gente descia. Lá, encontramos vestígio antigo. Aí a equipe retornou, e o Assis achou que deveríamos mudar o acampamento para um outro local, onde havia um poço melhor de água, que era aquele na cabeceira para baixo da pista, ali. Aí, lá montamos o acampamento. Eles saíram para Vilhena, para buscar suprimento e, enfim, tirarem as folgas, ficando eu, o Assis e o Raimundo, lá. Então os índios vêm e colocam estrepe no acampamento, o que a gente comunicou a Assis, que retornou para o acampamento. Então a gente fez uma expedição para Baia Rica, acompanhando o esporão da João Antunes, que levava até o ponto máximo mais próximo do Baia Rica, que é o Igarapé que cruza ali no meio da Terra Indígena. $\mathrm{E}$, bom, ali a gente foi observando que, naquele varadouro, um bom trecho continha também estrepe colocada pelos índios. Hoje se sabe que se tratava de varadouro, mas naquele tempo a gente via aquele caminho e achava que era caminho de anta, ou seja, de bicho, parecia de bicho, e só depois foi que a gente foi compreender o que era, um varadouro.

Antenor Vaz: Um caminho deles?

Rieli: É, um caminho de indígenas. E aí, depois, quando a gente teve essa compreensão, compreendeu também que toda aquela estrada feita pelos madeireiros, de mais de 40 quilômetros, que estava na área de cerrado era feita em cima do varadouro dos índios...

Antenor Vaz: As estradas dos madeireiros?

Rieli: Dos madeireiros, em uma área divisora de dois igarapés. Era o ponto mais alto, e esse divisor era o caminho de mudança dos índios de uma região para outra. Era fundo mesmo, muito bem batido. Então a gente foi nessa expedição e acompanhou até os vestígios deles, até o Baia Rica. Bom, lá, a partir dos vestígios observados, o Assis decide que pode confirmar a existência dos índios. Mas a gente não tinha conhecimento do trabalho naquela época,...era só questão de começar a deixar os brindes para começar a atrair os índios. E aí, lá, na beira do Baia Rica foram então deixados alguns machados, alguns facões, algumas panelas, né?. Foram então pendurados em um tapirizinho que fizemos lá. Aí 
retornamos, mas Assis achou que o acampamento deveria ser avançado um pouco mais para perto de onde estavam os brindes, certo? Aí a gente avançou passando pela pista que a gente abriu depois, uns cinco quilômetros adentro, até próximo daquele tapiri onde a gente encontrou a ossada.

Antenor Vaz: Hum... antes de chegar naquele acampamento que chamávamos de "avançado"?

Rieli: É... a ossada estava um pouco mais na frente. Aí montou-se acampamento, e a gente lá ficou. Começou a chover e começou a amolecer muito a estrada, daí o Assis achou melhor recuar de novo o acampamento e colocá-lo naquela baixada da pista.

Antenor Vaz: Que é bem pertinho de um outro acampamento dos índios, não é?

Rieli: É, no mesmo local do acampamento antigo dos índios. Aí a gente estava fazendo essa mudança, terminando, de tarde, de transportar a parte das coisas maiores. No outro dia de manhã, a gente foi pegar o restante das coisas que haviam ficado lá. Aí estava cheio de estrepe, inclusive dentro do nosso acampamento. Bom, viemos para esse outro acampamento, que foi onde a gente passou aquele período chuvoso. Dali foi de onde saímos para as operações fora da Terra Indígena.

Antenor Vaz: Mas você falou que você entrou na equipe em 1988. Foi exatamente o ano após a mudança na política do contato para o não-contato, não foi? Mas você, no seu relato, as atitudes estavam sendo para contato.

Rieli: É, o Assis ainda praticava aquela cultura antiga, pois havia participado daqueles trabalhos de contato com os Pacaas Novos, com os Cinta-Larga e com os Suruí. Daí, continuou com o mesmo modelo. Para mim estava correto, pois a gente estava chegando e seguia a orientação do Assis. Isso permaneceu até no ano seguinte, quando você chega, você que pensa num outro tipo de trabalho, com cuidado para se evitar o contato, implementando essa nova política. E aí, nesse período chuvoso, a gente ficou ilhado lá dentro, porque as pontes rodaram todas e o veículo que a gente usava ficou preso lá dentro. Então a gente andava $80 \mathrm{~km}$ para pegar mercadoria lá na estrada de Izidrolândia. $80 \mathrm{~km}$ para ir e 80 $\mathrm{km}$ para retornar. Levávamos cinco dias para fazer esse percurso e chegávamos no acampamento para fazer as incursões na mata.

Antenor Vaz: Atravessando mais de $10 \mathrm{~km}$ de alagado.

Rieli: É, aí, o local tinha duas estradas. Tinha uma estrada que era a 95 e tinha a 110, que era uma linha, em que até um trecho tinha uma estrada, mas depois era aberto por picada, era picadão mesmo, assim, por onde só passavam pessoas a pé, tropeiro. E era no baixo da serra, onde havia uns igarapés que alagava muito. E, assim, passava o período da chuva, caia muita chuva, e passávamos por lugares em que andávamos com água pelo peito. 


\section{Antenor Vaz: Era o baixão do Massaco e do Consuelo, certo?}

Rieli: Isso, eram dois igarapés. Em um lugar dava água pelo peito, pelo joelho, em outro lugar você tinha que nadar, às vezes, para poder passar. Cinco dias a gente gastava para buscar mercadoria e retornar ao acampamento. E daí a gente conseguia trabalhar 20,30 dias, ali na base, fazendo algumas caminhadas. E, assim, foi esse período todo chuvoso até o mês de junho do ano seguinte. Já em junho de 89, quando conseguiu-se entrar com outro veículo, que foi quando você estava entrando, a gente conseguiu transitar mais pela área. Naquele ano, as ações se concentraram na localização dos invasores, na tentativa de afastá-los da Terra Indígena. Isso durou até o final do ano, quando houve as operações, e quando foi feita a extrusão daquele pessoal. A área já era uma área demarcada, uma unidade demarcada, porque já era a Reserva Biológica do Guaporé. E, com isso, dispomos de uma ferramenta, um instrumento para a gente fazer com que o IBAMA cumprisse o seu papel de garantir a proteção da terra. Só que, para a gente, teve um custo muito grande, pois era a gente que vivia lá, com o Antenor na coordenação, e eu que era morador no local. O IBAMA vinha e fazia as operações e ia embora, e a gente era quem ficava no local, sofrendo todo tipo de ameaça, porque quando os agentes do IBAMA eram questionados sobre seus acertos com os madeireiros, pois era um pessoal corrupto, eles diziam "Não, a gente tá vindo aqui porque a gente é obrigado. A FUNAI que tá denunciando e a gente é obrigado." E aí, recaía tudo em cima da gente. Era ameaça o tempo todo, e a gente tinha que estar fugindo, se desviando muitas vezes. Por um lado, para mim era ruim, porque eu morava na cidade, mas por outro lado, ajudava, porque a gente já conhecia algumas pessoas, e mesmo lá, entre os madeireiros, havia pessoas que eram amigas da gente e avisava, "Olha, vocês evitem tal local porque o pessoal tá esperando vocês lá, né?”. Então, isso acabou facilitando, por um lado. Como estratégia, a gente se refugiou dentro da Terra Indígena Rio Branco, por um ano, naquele período chuvoso que foi de 1989 para 1990 e, de dentro da Terra Indígena Rio Branco, se fazia as expedições, pelo outro lado, em que não havia a necessidade de passar nas linhas onde estavam as coisas inflamadas. Daí a gente continuou o trabalho de localização por dentro.

Antenor Vaz: Agora, como foi que você foi descobrindo esse trabalho de localização. Porque, quer queira quer não queira, foi-se construindo uma cienciazinha ali, em termos de...

Rieli: Bom, eu,... assim, eu tinha um conhecimento da mata. Então a mata para mim não era segredo. Eu sabia fazer uma leitura da mata, ler aquilo dali. Porque era acostumado a fazer uma leitura de rastro de caça, um batido de bicho ou um batido de gente na mata, para mim era muito fácil se adaptar para aquela situação ali de rastrear índio, de estar localizando vestígio. Assim, depois que chegou o Antenor com uma outra visão, na verdade me capacitando para esse conhecimento que nos direcionava de forma diferente para lidar com a questão, 
fui despertando para entender o quebra-cabeça, pois é algo que vai intrigando a gente, a gente quer resolver. Assim, em cada expedição, a gente descobria uma coisa nova.

Ana Suelly: Por exemplo?

Rieli: Ah, você encontrava determinada coisa que você achava que era do povo tal. Parecia com o povo tal. Então, assim, parecia com tal índio. Aí, de repente, na outra expedição você encontrava uma outra coisa que já desmontava toda aquela hipótese. Então era um quebra-cabeça saber. Assim, ia despertando a curiosidade de buscar mais informações, e a gente que gosta da mata...! E, bom, aí o retorno para Terra Indígena Rio Branco que era esperado, tendo sido prometido aos índios, não ocorreu. E eu também já estava gostando do trabalho, aí a gente continuou com o que está aí até hoje.

Antenor Vaz: Mas, por exemplo, esse conhecimento que você tinha da mata, eu me lembro de uma coisa simples, um detalhe. Na primeira exposição da qual participei com vocês, a gente estava andando no caminho dos índios, no campo, e você ia na frente e disse "- Oh, os índios, eles passaram por aqui indo." Então eu disse "- Mas como é que você sabe que os índios foram e não vieram?”. Você respondeu “- Não, porque o capim tá puxado para lá.” Então é esse tipo de conhecimento que o Rieli tinha da floresta, né, da mata, de fazer leituras da presença animal ou humana na mata. Ele passava num canto e ele percebia se ali havia passado um bicho, se ali não havia passado um bicho, se ali foi cortado há quanto tempo, se foi quebrado há quanto tempo, se foi tal coisa que quebrou aquilo, se foi uma anta, por exemplo. Então, era esse tipo de conhecimento que de uma certa forma toda pessoa que é da floresta ou que convive com a floresta percebe. Agora, você faz a leitura que você quer, você pode ler isso para descobrir onde as caças estão, que é normalmente o que as pessoas fazem. Porque não se anda na floresta porque se acha lindo. Ora, pode até ser, mas muitas vezes o andar na floresta é para buscar produtos da floresta, seja fruta, seja caça. E ai se vai treinando o olhar para isso. Então o Rieli, nesse sentido, e os índios que o acompanhavam na equipe tinham esse treinamento natural, em si. Mas como pegar isso daí e dizer: “- Mas não, a gente não está atrás de caça, mas procurando índios. ” E aí, isso, o Rieli desenvolveu numa rapidez estupenda, entendeu? E foi traduzindo isso, não era mais atrás de caça, era atrás dos índios.

Ana Suelly: Então, nesse contexto dessa área, foi o Rieli quem, digamos assim, liderou o trabalho?

Antenor Vaz: Totalmente, claro! Quando eu cheguei lá, já existia, eu não me lembro quantos, mas eram mais de 12 acampamentos indígenas que eles já tinham visto, já sabiam que existiam, já sabiam, já conheciam os caminhos, os varadouros principais dos índios. A dificuldade que havia era a de que isso 
estava sendo conduzido pelo Assis para fazer o contato, não é?

Rieli: É, e não havia uma preocupação em registrar essas informações, em sistematizá-las.

Ana Suelly: Era isso que eu ia perguntar. Vocês não fotografavam, nem registravam isso?

Rieli: A gente fotografava de uma forma, mas era uma forma diferente, ou seja, não tinha aquele olhar, não tinha aquele olhar para estudar, para comparar com outros vestígios, com outras coisas, para tentar ir identificando o povo. Era só confirmar se existia o índio para fazer o contato. Assim que foram os trabalhos de localização de índios isolados no passado. Para mim, o trabalho mais bem feito até hoje é foi o trabalho da Reserva Biológica Guaporé. É, foi a primeira terra demarcada sem estabelecer contato com os índios. Por que? O que aconteceu para se fazer um trabalho, assim, perto da perfeição, assim, né? Foi porque se uniu conhecimentos, o conhecimento que eu tinha da mata com o conhecimento que o Antenor tinha do contexto político e da organização de informações. Isso eu acho que foi o que deu certo, né, o tempero, essa coisa de você trabalhar em equipe com esses diversos conhecimentos. Quando você consegue agregar isso, você consegue tirar bons resultados. Essas coisas separadas, resultam em dificuldades de se fazer coisas bem perfeitas, acho que é isso, não é?

Antenor Vaz: Mas o que era interessante era que essas coisas estavam na cabeça do Rieli, só faltava, e foi um pouco isso que o Ari', que trabalhava na superintendência de Cuiabá, dizia, "Antenor, o pessoal já localizou uma quantidade grande de informações sobre os indios, mas olha aqui os relatórios que eles me mandam!’. Eram relatórios de duas páginas, no máximo. Então, a gente via, lia aquele relatório e deduzia que tinha muito mais coisa para ser dita, mas faltava a preocupação em fazê-lo. Por exemplo, na primeira expedição da equipe da qual eu participei, chegamos no acampamento dos indios,... enorme, enorme!. E qual foi a postura de quem estava à frente? Dizer "Gente, olha, vamos todo mundo agora, vamos tentar descobrir (...) o que a gente pode descobrir mais aqui, o que é que eles comem, o que é que eles não comem, como o acampamento foi feito, por exemplo? Foi feito com o que? Utilizaram facão ou não utilizaram facão? De onde eles tiraram a palha? De onde eles tiraram a madeira? Não é? O fogo, esse fogo é velho, é antigo? Tem osso, osso de que? Então, foi essa curiosidade despertada. Porque todos eles que são treinados nesse conviver com a mata, veem isso. Eles veem, só precisava um alguém dizer: "O que vocês estão vendo é importante, mas vamos botar isso no papel!’. Foi isso. Essa foi a grande sacada da história que une os conhecimentos? Ai tinha o Rieli, e depois foram-se agregando outras pessoas na equipe...pessoas que tinham esse conhecimento de mato, como o Carlinhos,

${ }^{7}$ Ariovaldo José dos Santos. 
o Mauro, o Paulo, o Alemão (que é o Altair ${ }^{8}$, e que veio bem depois).

Ana Suelly: Em que ano, mesmo?

Rieli: O Alemão, acho que veio em 1992, por aí.

Antenor Vaz: E a gente está falando de 1989. A partir daí, eu comecei a dizer a Rieli, "-Vamos ver isso que vocês veem nas expedições, como é que é no mapa?" A ideia era tentar colocar essas informações em um mapa. Ao mesmo tempo que devíamos plotar no mapa, era para informar o que víamos. Ah, a gente chegou num acampamento que tinha muitas coisas, mas o que era que tinha lá? Tinha isso, tinha isso, tinha isso e, assim, fomos registrando. A gente começou, então, a numerar os acampamentos. Numerar e botar as informações no mapa. E daí, a partir de um certo momento, não dava mais para ficar se lembrando dos dados. Era necessário uma tabela. Então foi feita uma tabela, que tinha um conjunto muito grande de informações. É exatamente esse trabalho que a gente fala que é muito escasso. E quem é hoje que consegue fazer o que o Rieli faz? Encontramos, hoje, pessoas que podem fazer o papel que eu fiz. Qualquer pessoa, mas que tenha a preocupação de escrever um relatório. A própria exigência de informações para se definir uma Terra Indígena obriga as pessoas a chegarem àquelas informações, de uma certa forma, sistematizadas. Isso não é muito dificil, mas difícil é você descobrir pessoas com essa habilidade e que queiram ir para campo, para o mato. Agora, por isso é que eu fico perguntando para o Rieli, tentando tirar dele, como foi que ele aprendeu isso, como é que ele transformou aquela habilidade de caçar em localizar índio? Esse que é o grande segredo.

Ana Suelly: Como é que você pensava o índio nesse momento em que você começou a desenvolver toda essa metodologia? Quando você começou a identificar que índio é esse? Qual era o sentimento com relação aos índios?

Rieli: Bom, eu, assim, primeiro passa daquela coisa do preconceito para você começar a conhecer o índio. Ou seja, a gente começou a conhecer o índio nessa relação que se estabelece com o pessoal do Rio Branco, não é? E como é que você começa a conhecer o índio? Foi nesse momento que fomos para a mata com eles e ficamos esse tempo todo. Aí você está lá, na beira do fogo, de noite, conversando, e eles contando as histórias deles, por exemplo, como é que foi a época de contato, essas coisas difíceis, não é? Então, para quem gosta da mata, ouvir essas histórias deles, mexe muito com a gente. Ou seja, quantos morreram com sarampo, com doença, o quanto foram perseguidos. E aí, a gente passa a defendê-los, porque você vê que são pessoas, grupos de pessoas que estão ameaçadas pelas nossas ações, de forma natural você já começar a defender,...e cada vez mais a gente vai se aprimorando. A gente teve sorte de trabalhar junto

${ }^{8}$ Altair José Algayer, sertanista. 
com pessoas boas, que foram dando essas dicazinhas para a gente também. Mas essa questão é muito mais, acho que humana mesmo, não é? De você ver que as pessoas estão ali prejudicadas pelas ações nossas mesmo.

Ana Suelly: O que é também fascinante, um jovem, tão jovem, centrar, fazer uma opção de vida, que é como um sacerdócio. Pelo tempo que você fica no mato, e esse apego à causa. Eu acho que o que é mais dificil, hoje, é encontrar pessoas que reúnam todas essas qualidades, a experiência com o mato, o sentimento de compartilhar dor, e outras qualidades. É algo muito difícil, não é? E uma pessoa esclarecida como você, com sua experiência, não só por conhecer o mato. São muitas qualidades numa pessoa.

Rieli: Uma coisa é fundamental ao se trabalhar com índios: é você ter paciência para ouvir, ter humildade; isso é o fundamental, é o básico. Se você não tiver paciência, não tiver a capacidade de ouvir, e não tiver essa humildade de aprender, eu acho que não vai conseguir nada. Se você chegar numa comunidade indígena e você tiver essa capacidade de ouvir as pessoas, e tiver essa humildade de aprender com eles, você se insere, e você se enturma com eles. E cada vez que você vai convivendo com eles, você vai se apaixonando cada vez mais, gostando daquela coisa... E na medida em que a gente vai gostando, a gente vai procurando se aprimorar um pouco mais na questão de compreender melhor, do contexto mais geral, da questão indígena...

Ana Suelly: E o que foi que você aprendeu com os índios que o ajuda no trabalho de localização dos próprios índios?

Rieli: Deixa só eu concluir. A gente foi buscando mais ferramentas para a gente poder trabalhar. Eu não sabia manusear uma carta, ou seja, um mapa. Eu não sabia fazer a leitura de um mapa, e não sabia mexer num computador. Eu não sabia mexer numa bússola. Eu não sabia manusear num GPS! Isso, quando a gente começou a trabalhar. E aí, na medida em que a gente ia tendo as necessidades, a gente ia buscando se aprimorar para poder trabalhar de uma forma mais produtiva. E essa capacitação para atuar melhor, a gente nunca teve na Instituição. Tudo foi adquirido por iniciativa própria. E de pessoas que tiveram paciência em ajudar a gente. $\mathrm{O}$ Antenor foi uma pessoa que me ajudou muito nesse aspecto. É, então foi dessa forma, a gente buscando e achando pessoas que tivessem paciência para ensinar a gente. Mas a Instituição não me preparou para trabalhar com índio. E com os índios, a gente foi aprendendo. Então, a gente teve a oportunidade de trabalhar, com vários índios, em várias áreas, com vários povos. E isso enriquece muito, porque em cada local você tem uma experiência diferente. São coisas diferentes que você aprende, culturas diferentes, e isso vai te enriquecendo muito, isso vai te dando mais condição de entender a realidade e de trabalhar.

Ana Suelly: De conhecer... 
Rieli: É, embora quando você chega em outro local, ele seja completamente diferente, você já sabe, já tem instrumentos para saber como é que vai proceder ali, os cuidados que se tem que ter, as técnicas que vão ser utilizadas, e fica mais fácil de ir entrando em qualquer local novo, no qual você vai para trabalhar...

Ana Suelly: A primeira iniciativa de um sistema de proteção de índios isolados foi nessa área? De proteção, não de contato?

Antenor Vaz: Já existia uma frente chamada Madeirinha. Frente de contato Madeirinha. Mas existia a mesma preocupação que existia na frente Guaporé, mas com a Reserva Biológica. O Ari dizia que o pessoal do Madeirinha estava também localizando os índios, localizando vestígios, e inclusive chegaram a fazer um contato com os índios, mas os relatórios são muito superficiais. Eles não se sustentam diante de qualquer argumentação jurídica, entende? Não se podia pegar aqueles relatórios e utilizá-los como instrumento de prova, porque eles não eram substanciosos, entendeu? Eles não apresentavam a curiosidade necessária para montar um quadro. Um relatório dizia: "a gente encontrou um acampamento dos índios" e ponto. Ah, os índios comem muito jabuti. Mas, o que é que levou a dizer que eles comem jabuti? O que é que você encontrou? O tamanho desse acampamento, quantas pessoas possivelmente havia nele, quantos fogos havia, que instrumento eles usaram para fazer esse acampamento? Essa curiosidade, entendeu?

Ana Suelly: Não existia, então...

Antenor Vaz: Não, essas informações estavam na cabeça das pessoas, mas elas não colocavam isso no papel, e quando eu fui trabalhar, ninguém chegou para mim e me disse "olha, você tem que fazer um relatório que contenha isso, isso e isso". Mas, a curiosidade e o rigor que eu tinha, do ponto de vista do registro, eu tinha isso, e o Rieli tinha como perspectiva, encontrar isso, tinha rigor e tinha curiosidade, entendeu? Agora, como era que essa curiosidade e esse rigor não se refletiam na forma dos relatórios. E isso estava na função de um coordenador, de uma pessoa que coordenasse. Nesse aspecto, o Assis era importante porque ele era uma pessoa que tinha vivido vários contatos. Mas ele estava promovendo o contato. É, então, assim, não existia uma consciência que dizia "eu estou indo aqui e estou chegando porque eu quero criar uma metodologia de localização, ou eu quero sistematizar uma metodologia de localização". Não. Não tinha isso, mas eu tinha uma coisa muito clara na minha cabeça, que era a de que nós não podemos ter ações que desencadeiam o contato não é?

Ana Suelly: E isso vocês tinham?

Antenor Vaz: Sim, porque eu tinha lido toda a documentação dos sistemas.

Ana Suelly: Agora uma pergunta a respeito do contato. Não havia a 
preocupação com a localização dos índios? A ideia era a de estabelecimento imediato do contato?

Antenor Vaz: Inicialmente não havia preocupação de localizar, não é?

Ana Suelly: Já atuavam pessoas como Sidney Possuelo, Wellington, Apoena Meireles?

Antenor Vaz: Eles tiveram o grande insight de perceber que, embora eles achassem que estavam protegendo os índios ao desencadear o contato, a história de muitas décadas já mostrava que aqueles grupos que eles queriam proteger por meio do contato, mais da metade deles estava morrendo, isso sem a gente falar que a maioria dos contatos que foram protagonizados pelo estado foram contatos para limpar a área para algum projeto acontecer. Ou porque os índios estavam atacando em alguma região de colonização. Se fazia o contato porque iam construir a BR 364, a 169, 164, entendeu?

Rieli: O Carajás...

Ana Suelly: No caso do Guaporé, o trabalho de localização foi então marco na história do não contato?

Antenor Vaz: Não, em 1988 se definiu uma nova política, que era a do não contato. Só que o que acontecia era que as pessoas que eram membro das equipes tinham como referência prática o contato. Então, quando o Assis foi para a Reserva Biológica, a equipe de localização dos índios isolados da reserva biológica do Guaporé foi instruída que era para não fazer o contato. Mas, na prática, Assis não sabia o que fazer se não fosse o contato, entende? Então, eu me lembro que o Rieli, em uma das conversas que a gente teve logo que eu cheguei lá, disse assim para mim: - "Eu achei que me chamaram para fazer o contato”. Acredito que esse fato esteja na tese do Carlos Augusto. Rieli disse mais ou menos assim: "Eu pensei que era para quando a gente ver os índios, a gente sair correndo e agarrar os índios, que era para fazer o contato", entendeu? Então, voltando à sua pergunta, eu fui com uma visão muito clara que não era para fazer o contato. Eu sempre achei que os índios têm que ficar tranquilos, na deles. Se um dia eles quisessem, eles viessem. Agora, se você não desenvolve uma metodologia de contato, o que é que você faz para proteger os índios? E aí, para a gente, ficava muito claro que a grande ameaça para aqueles índios ali era a invasão do seu território. Então a gente tinha uma urgência de ter mais informações, as mais consistentes e rápidas possíveis, de modo, primeiro, que provasse que os índios existiam, que não era mentira, eles existem de fato. Depois, se eles existem, qual o território deles? Em seguida, deveria ser iniciado um processo de definição territorial para a demarcação de Terra Indigena. Era isso. Quanto mais informações fossem registradas, mais rápido era possível realizar a definição territorial. Quando eu cheguei, já tinha um volume grande de informações. Nas primeiras semanas, eu iniciei um pouco 
de registro disso, e logo a gente foi fazer a expedição, e, quando a gente voltou, eu me debrucei para sistematizar o primeiro relatório com as informações; já, o Rieli trabalhou com o mapa. Eu, eu não tinha o domínio da selva como tenho hoje. Já o Rieli, era o que tinha a compreensão de juntar as informações e colocá-las no papel.

Ana Suelly: Então, registrar sistematizando...

Antenor Vaz: Isso, uma metodologia foi sendo construída. Já havia sido feito um primeiro com vários relatórios e mapas, ai a coisa foi crescendo. Quando a gente se deu conta, dali estava surgindo um modo de trabalhar, uma metodologia de localização. Eu já estava fora da Reserva Biológica. Quando eu percebi, havíamos desenvolvido um jeito de trabalhar não apenas lá, mas em qualquer canto.

Ana Suelly: Essa visão e essa metodologia, esse caminho para o não contato, que passava pela identificação, localização e mapeamento, consistiu então na primeira experiência atestada?

Antenor Vaz: Isso, é isso que é importante. A sensação que eu tive e tenho, Rieli, é que, apesar de haver hoje várias pessoas que estão imersas na continuidade desse processo, não parece está evoluindo, certo?

Rieli: Eu acho que tem algumas frentes que estão conduzindo o processo nesse rumo. Acredito que o Fabrício ${ }^{9}$ faz um bom trabalho de registro, não é? O Guaporé, que continua com o Altair, não é? E há gente que faz um pouco. Hoje a gente tem muito registro levantado do Uru-Eu-Wau-Wau, mas não está formatado, contudo, por falta de tempo. Daí vem uma série de coisas. A política hoje da FUNAI é tirar a gente do mato e botar na cidade. E vai ficar localizando índios isolados lá da cidade? É uma consequência da demanda administrativa. $\mathrm{E}$ a gente ainda com um número reduzido de pessoas, então limita a gente demasiadamente. Há muita coisa para ser feita. Mas são duas frentes hoje que estão fazendo esse trabalho.

Antenor Vaz: E o Madeirinha também?

Rieli: O Madeirinha tem levantado as informações, mas não sistematiza tanto, embora registre. O Acre não tem essa metodologia. E outras frentes também não.

Antenor Vaz: Agora, o que eu estava colocando é o seguinte: vamos dizer que tem um jeito de se desenvolver um trabalho de localização que teve sua origem ali, na Biológica. Agora, o que eu pergunto é o que hoje avançou? Na atualidade, você tem muito mais tecnologia, imagens de satélite, do que a gente não tinha naquela época; você tem GPS que dispensa o trabalho de se trepar

${ }^{9}$ Fabrício F. Amorim. 
em árvore, como a gente tinha que trepar numa árvore ou então numa clareira gigantesca. Eu estou querendo compreender, assim, a coordenação, o trabalho de proteção para índios isolados no Brasil como um todo, o que é que avançou, da Biológica para cá?

Rieli: Quanto à proteção mesmo, essa tem regredido, porque hoje o que se tem é o fechamento das bases, por falta de recursos humanos. E em termos de localização também não avançou. E aí a razão, não é? Como se estabeleceu o sistema de proteção aos índios isolados na época que era constituído de três subsistemas: localização, proteção e contato. Eu acho que ainda é o modelo, o melhor até hoje, ainda. Também não se pode implementar ele como um todo. Ou seja, a equipe especializada na localização faz a localização ali, não é? Ou seja, o outro subsistema já assume a proteção, ou o contato, dependendo da situação ali levantada por essa equipe de localização que ia na cidade, via quais os grupos que tinha. Porque quando se fala de localização não só é aquela localização geográfica, nem só onde estão os índios, mas é uma coisa mais ampla. É necessário saber quem é o povo, qual o território que ocupa, qual é esse espaço que eles ocupam ali, para que ocupam. Aí vem aquela importância do registro, daquela metodologia que o Antenor desenvolveu lá, ou seja, o que ele consome, que tipo de caça, qual o tipo de material que ele utiliza, onde estão localizados esses recursos na Terra Indígena? E quais as ameaças que sofrem, se é do garimpeiro, do madeireiro, se essas ameaças podem ser revertidas, ou se é uma situação irreversível. Essa era a função da equipe de localização, de fazer esse trabalho. Então depois viria um dos dois subsistemas, o de proteção ou de contato. Mas isso não foi implementado, porque? Já existia a deficiência de recursos humanos naquela época, e essas equipes que foram para fazer a localização acabaram ficando ali presos e tiveram que continuar com o trabalho de proteção, ficando as outras referências sem serem trabalhadas. Eles encontraram situações muito difíceis, como o estado iminente de desaparecimento dos índios. Então, o sistema de proteção aos isolados acabou não sendo ativado. $\mathrm{E}$, assim, hoje nós temos um retrocesso nesse trabalho, que eu atribuo a duas questões: primeiro, por falta de recursos humanos, e aí não é só uma questão numérica, mas uma falta da qualidade mesmo, de conseguir selecionar pessoas com perfil adequado para esse tipo de trabalho. A demora que houve entre o concurso da FUNAI para repor recursos humanos, o fato de as pessoas com experiência com o indigenismo se aposentarem, outras vindo a falecer, tudo isso. E já não há quase pessoas para preparar os novos que estão vindo. Assim, hoje, não é só uma questão de quantidade, mas uma questão mesmo de qualidade que se perdeu. E a segunda questão, que também é muito forte, é a questão de se tirar o foco das pessoas de campo, do Coordenador de Frente, que na verdade devia ser a pessoa que deveria estar lá no mato fazendo o trabalho intermitente. Hoje, um coordenador de frente tem de fazer a gestão de pessoas, os relatórios financeiros, planejar, ou seja, executar, fazer tudo. Se 
o coordenador sai para fazer uma expedição de 30 dias, nesses 30 dias a parte administrativa fica parada, pois o seu substituto não pode assinar por ele, já que o Coordenador está no exercício de sua função. Nem uma folha de ponto do pessoal lotado naquela coordenação o substituto pode assinar. Há que se esperar o retorno do Coordenador, gerando situações de ameaças, como corte de ponto dos funcionários por falta de folha de ponto assinada. Eu acho que falta, na verdade, compreensão da natureza do nosso trabalho, por parte dos servidores da própria FUNAI, da sede central. É uma questão impeditiva das nossas ações. Eu vejo, por um outro lado, que a direção da FUNAI, por desconhecimento do que a gente faz e pela especificidade do trabalho, acha que somos nós que devemos nos adequar às legislações vigentes, e não tentarmos que criar uma legislação específica que atenda às necessidades das frentes. Isso me angustia muito. Me angustia muito porque a gente tenta argumentar, mas a legislação é rígida. A legislação, da mesma forma que ela é feita, se desfaz, ou se cria uma especial. E tudo isso traz consequências para os índios isolados. Qual a relevância que o Estado dá à questão dos índios isolados? Porque são tantas outras referências que estão aí ainda para serem trabalhadas, que nem se sabe se esses povos ainda estão vivos. O Estado não considera a natureza do nosso trabalho tão específico e que deve ser tratado de uma forma diferenciada. Assim, somos impedidos de achar às referências, o que facilita o extermínio desses povos.

Antenor Vaz: É mais fácil encontrar pessoas para fazer o serviço burocrático do que pessoas para ir ao mato fazer localização e que saibam identificar se realmente existe um grupo indigena isolado numa determinada região. Antes mesmo da gestão da FUNAI propor essa restruturação vigente, a angústia dos coordenadores de área já existia. Em 2006 e em 2007 já se externava a difícil situação vivenciada pelos coordenadores, que estavam se transformando em gestores administrativos. Eles perdiam 60 a 70\% do tempo deles resolvendo problemas administrativos na cidade, ao invés de permanecerem no mato coordenando um trabalho de localização. Imagino se naquela época da Biológica eu tivesse que ficar na rua o tempo todo, coordenando a parte administrativa?

Rieli: Naquela época, sabe como funcionava? A gente fazia o planejamento para ir para campo, um planejamento de 90 dias, e recebia um suplemento de fundo, e em dois dias se fazia uma compra. Uma compra justa porque você ia no comércio pechinchar, pechinchar mesmo, brigar, porque cada centavozinho ali, dava para comprar equipamentos bons e adequados ao trabalho. A gente fazia o dinheiro render, para levar mais coisas, atendendo às necessidades do trabalho. Quando a gente voltada do mato, um ou dois meses depois, prestava contas do recurso gasto e já solicitava novos recursos para a próxima expedição. Não havia a morosidade de hoje, que faz a gente passar ano esperando para fazer as compras para um trabalho de campo. 
Antenor Vaz: Rieli, voltando um pouquinho à Rondônia. Como é que está a situação dos isolados hoje em Rondônia?

Rieli: Bom..., Rondônia naquele tempo, quando se iniciou a nova fase, com uma nova política, foi criada a frente Guaporé, que naquele tempo era chamada de Frente de localização dos índios Isolados da Reserva do Guaporé, e a equipe de localização era chamada de "Equipe de localização dos Índios Isolados da Reserva Biológica do Guaporé". Essa frente era uma frente específica para aquela situação ali. Com o passar do tempo, surgiram outras referências no estado, e essa frente foi se desdobrando em outros trabalhos. Em 1998, foi definido o Massaco, e entre 1996 e 1998 se concretizou a demarcação da Terra Indígena Massaco. Já havia sido iniciado o trabalho no Omerê, onde se fez o contato com os Akuntsu e os Canoê. Se descobre também o Índio do buraco, aumentando para três os pontos de trabalho. E já se confirmaram a presença dos índios dentro da área dos Uru-Eu-Wau-Wau. Em 1992, apesar dos índios já terem conhecimento do fato, a missão da FUNAI confirma a presença dos isolados e a torna oficial em 1992, com uma parceria nossa com a frente Guaporé. Naquele tempo eu estava como chefe de posto no Trincheira, junto aos índios Amondáwa. E essa frente começou a se desdobrar abarcando todas essas referências, além das que existiam na região dos Karipuna, no Jaçí Paraná, no Capivarí, na Cachoeira do Remo, esta bem mais para norte do estado, na região do Baixo Machado. Fazíamos as coisas mais efetivas no Guaporé e na região do Uru-Eu-Wau-Wau, e nos outros pontos, nossa ação era mais eventual, de alguns meses. Quando fazíamos uma expedição nos Uru-Eu-Wau-Wau, era nas duas referências que a gente trabalhava, pelo menos duas vezes por ano, ou seja, duas expedições por ano e, assim, a gente levava o trabalho de forma precária, com um quadro reduzido, mas ainda havia a possibilidade de terceirização de serviços de mateiros ou mesmo de piloto de barco. Então conseguíamos compor as equipes com um mínimo de pessoas que continuassem o trabalho. Assim foi até 2009, quando ocorre a restruturação, que foi quando se criou a frente Uru-Eu-Wau-Wau, voltada também para aquelas referências de dentro dela e algumas referências na região do Jaci, do Capivari, do Bom Futuro, e da Cachoeira do Remo. Jaci, a gente sabe que não existe mais, se existia, ou os índios morreram ou estão refugiados dentro da Terra Indígena Uru-Eu-WauWau, porque não tem mais matas por lá, só pasto. Na de Bom Futuro, também, muito provavelmente, já não existe pessoas por lá, porque várias expedições já foram realizadas na região e não foram encontrados vestígios. Quando a gente veio para assumir a frente Uru-Eu-Wau-Wau, a gente passou um período para implementá-la, iniciando do zero. Como tinha uma terra definida e os isolados já haviam sido confirmados, foi possível estabelecer duas bases mais fixas, Bananeira e Cautário, que estão mais próximas dos isolados, com grande pressão de pesca e caça. Eram cinco servidores novos, auxiliares, e uma leva de servidores oriunda de empreendimentos, em decorrência de uma intimação 
da 429 e de Jirau, que funcionou um ano, e acabou no ano seguinte. Iniciamos em 2010 e, em 2011 e em 2012, já não tínhamos mais equipe; em 2012, os funcionários concursados, os auxiliares de indigenismo já não estavam mais na Terra Indígena, porque são pessoas que foram selecionadas sem nenhum perfil para o trabalho de campo. O fato é que não tem mais ninguém em campo. Hoje, então a frente Uru-Eu-Wau-Wau, que tem duas bases montadas, com uma boa estrutura para se trabalhar, tem três servidores, comigo, por teimosia minha, pois, pela concepção da FUNAI, eu estaria lá em Ji-Paraná coordenando os dois servidores. Essa situação nos fez os chefes de serviço que estão em campo, essa escassez de gente, fez fechar a base Cautário, uma base que é recomendada desde o relatório de identificação da Terra Indígena Uru-Eu-Wau-Wau, em 1983/1984, em razão das invasões, da grande pressão que sofria aquele local ali. Mesmo com o auxilio dos Amondáwa, não foi possível manter a base aberta, tivemos que fechá-la.

Ana Suelly: Atualmente, quantas e quais são as referências em Rondônia?

Rieli: Hoje, há esses dois povos confirmados dentro da Terra Indígena Uru-EuWau-Wau, um grupo que a gente não sabe de que povo é, e que possui a maior população da Terra Indígena, bem expressivo, e um outro grupinho pequeno, Jurureí, que fica no extremo nordeste da Terra Indígena.

Antenor Vaz: E Wyrapara'ekwara, qual é?

Rieli: Wyrapara'ekwara é esse do sul, o grupo grande.

Antenor Vaz: O que você acha que é parecido com o da reserva do Massaco?

Rieli: Eles têm algumas semelhanças, mas não é o mesmo povo, com certeza. Wyrapara'ekwara é nome que os Amondáwa deram para eles. O corte de cabelo deles é diferente. Traduzem como gente que tem arco, gente que tem o arco com buraco. Deve ter alguma coisa, algum buraquinho no arco. Wyrapara é o arco.

Antenor Vaz: Não tem agricultura?

Rieli: Não, não têm agricultura. Nesse aspecto eles parecem com os do grupo do Massaco, mas os tapiris são diferentes. Os do Massaco são do tipo rabo de jacu, que têm a palha colocada meio na vertical, escorada na estrutura de madeira. Os tapiris do grupo grande são tapiris mesmo, cobertura meio alongada sem parede. E só fazem esses tapiris no período de chuva, no período de seca vivem a céu aberto

Antenor Vaz: Dormem no chão?

Rieli: Dormem em rede, mas pode ser que haja também pessoas que durmam no chão.

Ana Suelly: Não acharam nenhuma esteira? 
Rieli: Não, não encontramos esteiras.

Antenor Vaz: Os Nambikwára, por exemplo, não fazem esteira, usam folhas de palha ou pacova.

Rieli: Não vimos sinais.

Ana Suelly: Mas é rede feita de que?

Rieli: Feita de fibra de tucum, e são semelhantes também a do pessoal do Massaco. São grossas as cordas e bem espaçadas; fazem um marico também, como fazem os grupos do Vale do Guaporé, até os Akuntsu, todos ali fazem marico. Os do grupo do Massaco têm o cabelo na altura do ombro, ou mais comprido, e os da Terra Indígena Uru-Eu-Wau-Wau têm o cabelo raspado nos lados e só um topetinho tipo moicano; fisicamente, pelo menos os dois avistados, são baixos, gordinhos e fortes, com uma estrutura cintelada, e os do Massaco são um pouquinho mais delgados.

Ana Suelly: Trabalham o barro, fazem panela de barro?

Rieli: Não, nenhuma cerâmica.

Ana Suelly: Não cozinham, só moqueiam

Rieli: Só mosqueiam e muito mal mosqueado, são os primeiros índios que eu vejo que comem cru, quase que cru, conforme relato dos Amondáwa. A gente encontrou um acampamento que eles tinham deixado há dois dias, no qual os vestígios estavam muito vivos; havia lá um osso de tamanduá, deixado por eles, que estava vermelho de sangue.

Ana Suelly: Os Xetá, quando foram localizados, não tinham panela, mas o Aryon encontrou a palavra para panela na lingua Xetá, posteriormente, e eles the explicaram que tinham perdido a panela.

Antenor Vaz: Mas eles usam aquelas panelinhas de palmeira?

Rieli: Usam.

Ana Suelly: Para colocar o mel.

Rieli: Mais para coleta de mel.

Antenor Vaz: Os Nambikwára também não têm panelas de barro, mas eles usam aqueles tipos de panela para fazer mingau, só que eles faziam o que, ou eles botavam duas panelas, uma dentro da outra e colocavam nela o milho pilado com pouca água, no fogo, ai logo logo aquilo ferve, e quando queimava uma e começa a queimar a outra, o mingau já estava fervendo e já bem grosso. Eles também cozinhavam colocando seixos rolados na fogueira, muitas pedras, e jogavam dentro da panela com o mingau, assim fervia e depois de retirado da pedra, acrescentavam água para desunerar o mingau e esfriá-lo, pois eles 
não bebiam quente.

Rieli: É curioso esse povo lá, pois não pegam panela, nem panela de alumínio. Antenor Vaz: Os do (Massaco) pegam.

Rieli: Na expedição que a gente fez varando do Cautário para Bananeira, a gente tinha como objetivo levantar vestígios e também passar nas malocas dos Amondáwa, da época do contato, porque a FUNAI não as conheceu, não foi na maloca dos Amondáwa. A gente tinha também esse propósito de registrar o local dessas malocas, e na primeira maloca que a gente passou, 30 anos depois do contato, estavam lá as panelas perfeitinhas ainda, algumas que sobraram, porque havia algumas muito cortadas de facão, naquele tempo alumínio era grosso, bem forte mesmo. Dois meses antes, os índios tinham tirado uma pupunheira, cortando-a para fazer arco, e as panelinhas continuaram ali.

Ana Suelly: Eles não têm peneira?

Rieli: Não encontramos até agora, mas certamente não, agora o patoá eles consomem, mas não sei se eles têm uma outra técnica de amolecer o patoá, ou esquentar uma água de alguma forma para poder amolecê-lo.

Rieli: Bom, é com esses grupos que a gente está trabalhando, só ali nessa frente, fazendo esse trabalho, mas as outras referências, a gente não pode ainda trabalhar. Acredito que elas nem existam mais, só se os índios estiverem refugiados na Terra Indígena.

Ana Suelly: Que referência é essa?

Rieli: É uma referência que havia no Jaci-Paraná, perto dos Karipuna, para o sul e sudeste da Terra Indígena Karipuna, e a referência Guaporé, que a gente ainda vem trabalhando e mantendo a proteção do índio do buraco, mas sem condições de avançar em outras referências.

Ana Suelly: No Massaco, são, então, duas bases?

Rieli: No Massaco, são duas bases

Antenor Vaz: Agora esses Wyrapara'ekwara, eles atacam?

Rieli: Não, não há nenhum registro de que eles tenham atacado alguém.

Antenor Vaz: Eles se defendem como?

Rieli: Colocando estrepe, mas estrepe é uma coisa bastante comum entre os índios para defender o território deles.

Ana Suelly: O que tem me surpreendido é que parece que os grupos que se defendem atacando de forma mais bélica mesmo, existe mais repressão com respeito a eles. 
Rieli: Mais repressão ou sofreram tanta repressão que foram obrigados a ceder ao contato.

Antenor Vaz: É isso que eu acho interessante nos índios do Massaco. A forma com que eles defendem o território. Para os invasores fica parecendo algo meio inofensivo, mas estes não tinham medo de passar com o caminhão na estrada, porque nunca havia relato de ataques dos índios.

Rieli: E como se tratava de um grupo que não oferecia resistência, na época dos seringais, não havia necessidade de extermínio pelos não-índios, nem de contato pela FUNAI.

Antenor Vaz: O único fato que a gente ainda não conseguiu entender, é aquele local com muita ossada no Massaco, ossada de uma pessoa, muito machado de pedra e umas canequinhas de seringa. Mas, quais os impactos hoje em contraste com os impactos no passado?

Rieli: No início da década de 1980, avançava a frente de expansão com a pavimentação da 364, com o incentivo para a vinda de pessoas para Rondônia. Da 364 foram construídas as estradas secundarias e por essas estradas a ocupação da terra foi crescendo, chegando às áreas onde estavam esses povos. Então a pressão era muito forte, culminando com a exploração da madeira que, naquela época, era o forte, além de um garimpo. Assim as matas foram sendo devoradas e as pessoas avançando, avançando, ficando só mesmo as unidades que hoje sobrevivem nas terras indígenas, reservas biológicas, Reserva Estadual, Parque Nacional. Contudo, essas unidades de conservação do estado, como o Parque Nacional e a Reserva Biológica, só estão protegidas onde há indígenas. A floresta nacional do Bom Futuro, por exemplo, está hoje desmatada. A Reserva Biológica só não tem invasores por causa de um trabalho da FUNAI, assim como é o caso da terra do Rio Branco, que não tem invasores, por causa do nosso trabalho de proteção aos índios isolados que lá vivem.

Antenor Vaz: A Terra Indígena do Massaco faz divisa com a Terra Indígena Rio Branco, e nesta Terra Indígena, por um bom periodo, houve venda de madeira, mas a gente tinha um pacto com os índios, segundo o qual eles poderiam fazer o que quisessem com a terra deles, mas eles não podiam entrar na Reserva Biológica.

Rieli: O pacto era para não passar do Colorado, que estava na terra deles, e do Parque Nacional do Pacaas Novos; este está encravado no âmago da Terra Indígena Uru-Eu-Wau-Wau, e sua proteção é feita pela FUNAI e pelos índios do entorno. Trata-se de uma proteção solidária. São as áreas mais bem preservadas, diferentemente das demais que sofrem grandes invasões e grande desmatamento. Com os assentamentos e empreendimentos, como a 429, que tem sido pavimentada nesses últimos três anos, somados às construções das hidrelétricas de Jirau e de Santo Antônio, no Madeira, proporcionam um impacto 
permanente e crescente na Terra Indígena. A 429 margeia todo o limite da terra dos Uru-Eu-Wau-Wau, desde o nordeste, ao sul da terra indígena, passando a $15 \mathrm{~m}$ do limite desta. A pavimentação da 429 traz a mecanização, o resultado é observável em imagens de satélite, com um recorte do vermelho contrastando com o verde. Nas áreas de assentamento do pequeno agricultor que fazem limite com a Terra Indígena, o agricultor para obter um cabo de enxada, depende da mata da Terra Indígena, aí vem a caça, a pesca, inclusive a pesca esportiva, o que resulta na invasão de áreas de Terra Indígena, como tem sido o caso com o crescimento do município de São Miguel, o qual se tornará uma cidade, e que vem crescendo e vai se tornar uma grande cidade, a cidade maior daquele eixo, localizada a seis quilômetros do limite da Terra Indígena. Além do fato de que, desse município se expandem plantações de soja e de arroz.

Antenor Vaz: Situação similar à do Xingu...

Rieli: Atualmente não há tanta exploração de madeira porque há vigilância em Rondônia, com órgãos oficiais atuando nesse sentido. O Ibama, de uma forma menos atuante, se inibiu, mas a Policia Ambiental é bastante atuante, de forma que hoje não está muito fácil a ocorrência de grande retirada de madeira de áreas indígenas, embora ocorram pequenas retiradas. Os empreendimentos do complexo de hidrelétricas também não deixam de trazer impactos. A gente sabe que essa história de construir escadinha para peixe se desviar e se reproduzir, na prática, não ocorre. Peixes que se reproduzem localmente, não são abalados, como a traíra, o cará, o tupinaré e outros, mas peixes migratórios, como a matrinchã, a jatuarana, que descem e sobem rios para desovar, estes sofrem impacto, pois têm o seu processo natural de desova interrompido. Com a 364 projetada para ligar Porto Velho a Manaus, e alcançar o interior da Bolívia, Rondônia vai se tornar um local estratégico, de fácil escoação e local de geração de energia. A ligação com o Pacífico já é uma fato, e com o Caribe, previsto com a reativação da 163, a que liga Porto Velho a Manaus, Rondônia vai ter uma certa estrutura e cada vez mais atrair investidores.

Antenor Vaz: Então, os impactos hoje estão direta e indiretamente relacionados à 421, à 429, ao PCH Jamari, Santa Cruz, em Monte Negro, e Canaã.

\section{E Jamari, em que estágio está?}

Rieli: Jamari já está até funcionando. Nesses dias, eu passei lá e vi que o lago está represado, embora eu não tenha estado em suas instalações, acredito que esteja em funcionamento, e afetará diretamente a Terra Indígena Uru-Eu-WauWau.

Antenor Vaz: É muita coisa. Isso só em relação ao Uru-Eu-Wau-Wau e ao Massaco. 
Rieli: O Massaco está um pouco fora do eixo dessas estradas. Está um pouco mais resguardado, por enquanto.

Antenor Vaz: Guaporé tem a linha de transmissão Porto Velho Araraquara e o PCH Bacia do Rio Branco, além da 429.

Rieli: O PCH do Rio Branco acaba afetando o funcionamento do Rio Branco, e já está em funcionamento, além de várias construções, como a de Figueira, da Boca do Figueira.

Antenor Vaz: Todos PCHs?

Rieli: Todos PCHs. Tem o da Cabeceira do Jacaré, tem o da Enco, um outro do Cassol, na Boca do Paulo Saldanha, um outro sendo construído no Cachimbo, que é também no Rio Branco, e mais dois no Figueira, que é tributário do Rio Branco. Agora, o impacto lá para baixo é muito grande, para baixo das usinas, pois estão todas acima da Terra Indígena do Rio Branco.

Antenor Vaz: E na terra indígena do Rio Branco, já diminuiu a quantidade de água?

Rieli: O regime das águas lá era assim, baixa no período de seca e alta no período de chuva, mas hoje não há mais um período de seca e um período de chuva. O rio pode baixar ou encher no período de seca, apesar de se falar que PCHs são grandes reservatórios. Com os impactos, o tracajá está à beira de extinção no Rio Branco, porque o tracajá tem aquele local de desovar, naquele assentado da praia, e desova ali porque sabe qual é o período que vai chover, preservando seu local de desova a salvo, podendo os bichinhos saírem na época de chuvas. Hoje, o tracajá desova e, de repente, o rio enche, então vem o sol e cozinha os ovos todinhos, de forma que os tracajás não estão mais reproduzindo. Impactos como esse são inúmeros.

Antenor Vaz: A energia gerada pelos PCHs vai para onde?

Rieli: Elas estão todas interligadas e a energia produzida é vendida ao governo. Ocorre que, se houver um apagão na região São Paulo, Rondônia é igualmente afetada.

Antenor Vaz: Agora, gostaríamos que você falasse sobre a língua dos índios no trabalho de localização.

Rieli: É um exercício que a gente tem que fazer no trabalho de localização. Se não soubermos que línguas eles falam, a comunicação vai ser precária.

Ana Suelly: Quando vocês estão fazendo a identificação, a língua também é considerada?

Antenor Vaz: Quando você localiza a língua indígena, se localiza muito mais pelos troncos linguísticos, se é um grupo Pano, um grupo Jê, etc. Antes não 
era assim, antes os estudos foram todos feitos a partir da cultura material, da arqueologia, dos tambaquis, por exemplo.

Antenor Vaz: Existe correlação entre cultura material e língua? Você dizer assim, "todo Tupí é agricultor", ou "todo Tupí tem cerâmica, faz cerâmica”?

Ana Suelly: Veja bem, às vezes a gente tem que recorrer à arqueologia. Por exemplo, Eurico Miller, de acordo com os resultados de sua pesquisa em Rondônia, propõe que do tronco Tupí, Karitiana, durante um tempo, não praticou a agricultura e o cozimento. E na realidade, as línguas da familia Arikém, apresentam inovações muito marcadas, então há que considerar que uma língua reflete a cultura de seus falantes, a história de seus falantes.

Antenor Vaz: Esse conhecimento, para um trabalho de localização, seria imensamente importante. Supomos que nós estamos localizando um grupo indígena, e ele não tem agricultura, não tem cerâmica, usam moqueado, caçam com borduna, e o que isso leva à uma língua? Existem estudos que associam cultura material à língua?

Ana Suelly: O Professor Aryon, em seu artigo "Agricultura Tupí pré-histórica na Amazônia" reconstrói para uma época entre 5.000 e 6.000 anos atrás, um vocabulário com significados que, como ele diz, implicam o conhecimento e a prática de atividades associadas à agricultura pelos falantes do Proto-Tupí. São exemplos de suas reconstruções ** yo/ ye 'roça', com cognatos encontrados em Tupi-Guarani *ko, em Awetý ko, em Mawé ko yo, em Juruna kúá, em Xipáya ku-a, em Mundurukú kə 'roça de mulher', em Kuruáya ki; em Arikém yga e em Karitiána ya, em Tupari e Makuráp ye, e em Kepkiriwát go, em Mondé Gavião ka, Paitér e Zoró ya, Cinta-Larga yga e em Ramaráma Káro na-čéj, na-čo. Outra reconstrução feita por ele é o tema **čit 'cavador', que corresponde ao Tupi-Guarani *cir, ao Awetý tit, ao Mawe ti-?i, ao Mundurukú šit e ao Tuparí sit e ao Makuráp tìt 'espada'.

Antenor Vaz: Esse pau pode ser usado para arrancar tubérculo, não é? A gente encontra dele no Massaco.

Ana Suelly: Os Zo'é possuem essa palavra, que me foi comunicada por Boj. Ele também me mostrou o instrumento. Se cognatos de uma forma linguística são encontrados em todas as línguas de uma família e em todas as famílias de um tronco linguístico é porque ela teria existido na língua ancestral.

Antenor Vaz: Rieli, e essa questão da língua com respeito aos indígenas de recente contato?

Rieli: É, já se fala há algum tempo, que as pessoas que trabalham com os povos de recente contato devem aprender a língua para poderem se comunicar com o povo. O que é extremamente importante, eu acho. Em situações de contato, você ficar dependente de um intérprete, quando muitas vezes ele simplifica 
aquilo que você quer transmitir. Isso aconteceu comigo nos Korubo. Os índios queriam determinada coisa, e eu não podia dar,. porque eu não podia dar aquela coisa, e o índio Matís traduziu assim, ele não vai dar. Esse comportamento nos coloca em uma situação complicada. Mesmo de uma forma inocente, do tradutor, quando traduz sem maldade. Mas há casos pensados, em que o índio transmite aquilo que ele quer, ou seja, aquilo que interessa a ele.

\section{Antenor Vaz: Uma leitura política?}

Rieli: Então, você não pode ficar a mercê de um tradutor. Você tem que ter uma compreensão do que está sendo dito, razão pela qual se você trabalha com um grupo, tem que aprender a língua desse grupo. Embora você não tenha o domínio pleno daquela língua, você saber o rumo da conversa e poder intervir, conhecer a língua é fundamental.

Antenor Vaz: Agora, por exemplo, para a Coordenação Geral de Índios Isolados e de Recente Contato, o Uru-Eu-Wau-Wau é de recente contato. Seria uma atribuição da frente trabalhar com eles? Você me disse hoje que o seu foco atualmente são os isolados. Então, é nesse sentido que eu pergunto, e os de recente contato? Na perspectiva da política de proteção a esses grupos, como está sendo?

Rieli: Bom, está meio complicado, porque em decorrência da política, eu acho que eles vão ser jogados no ralo comum aos outros

Antenor Vaz: Vão sair da CGIIRC? Só os isolados vão ficar? o setor RC vai sumir? Vai ficar só o CGII?

Rieli: Se forem considerados como recente contato, no meu caso, que sou da frente Uru-Eu-Wau-Wau, nós não temos condições de trabalhar com os isolados.

Antenor Vaz: Foi uma opção da Frente ou orientação da Coordenação?

Rieli: Não, não foi orientação da Coordenação, foi uma opção, ou seja, eu coloquei assim: "Eu não tenho condições de trabalhar com os índios de recente contato e com os isolados ao mesmo tempo, pois não tenho pernas para tanto." Senão a gente falaria que estaria protegendo os isolados, entre aspas. Os índios estão lá, sobrevivem porque eles têm a habilidade de sobrevivência, pois a gente não consegue proteger eles. A gente consegue protegê-los das grandes invasões, com retirada de madeira. Invasões de terra. Porque mesmo hoje com as terras demarcadas ainda há aqueles que invadem, os grileiros, por exemplo. Há organizações formadas, com até 10.000 associados, para invadir a Terra Indígena Uru-Eu-Wau-Wau. Agora mesmo, no ano passado, havia uma mobilização desse tipo. A associação do Vale do Guaporé, dos Agricultores do Vale do Guaporé, encabeçada pelo Hermes, que é um cara de Seringueiras, está articulando nesse sentido, reunindo 10.000 associados mobilizados para invadir a Terra Indígena. A gente foi passando essas informações para a Polícia Federal, 
e agora no final do ano ocorreu a prisão dele, evitando, assim, que a invasão ocorresse. Então, nessas grandes ações, a gente consegue atuar de uma forma mais precisa, preventiva. Mas, um garimpeiro que joga uma mochila nas costas e entra em uma área de uns 800 e tantos quilômetros de perímetro, como é que você dá conta, ou mesmo confirmar se o garimpeiro entrou ou não na área. Então, os índios sobrevivem porque eles têm as estratégias de sobrevivência. E aqui e acolá a gente sabe que tem um pesquisador de garimpo que vai lá dentro. A caça, é uma coisa que ocorre mais na periferia da Terra, mas traz impacto também, e em algum momento pode haver confronto com os índios, porque estes utilizam regiões que estão muito próximas do limite de sua terras.

Antenor: Não tem mais aqueles caçadores profissionais?

Rieli: Não, nessa parte de Rondônia não tem mais aquele caçador profissional que vive de vender carne de caça.

Antenor Vaz: Carne de paca?

Rieli: Aqui ou acolá, pode até ser, quando alguém da cidade encomenda uma paquinha, mas não é como no Amazonas, em que há a cultura de caçar para comércio. A caça ocorre nas áreas de assentamento, com o pequeno agricultor. $\mathrm{Na}$ área que tem limite com fazenda não há problema de caça. Porque o fazendeiro, que cria boi ou soja, não quer que o peão dele saia das atividades dele para ir lá caçar. Ele prefere dar a carne para o peão comer. Então, a gente tem menos problemas nessas áreas. Mas em cidades de pequeno assentamento, a situação é bastante problemática. E o problema ocorre há alguns poucos quilômetros da borda limítrofe da Terra Indígena. Já com respeito a pesquisador de minério, já fizemos uma apreensão, em 2010. Eles estavam em três e nós os pegamos lá no Calcário, quando eles já estavam saindo, depois de uns 60 dias dentro da Terra Indígena. Foram pegos em sequência. Os dois primeiros diziam "não sou pesquisador", "não sou garimpeiro", "fui quebrar castanha, e me perdi, estava perdido aí dentro." Só que tinham pedras, bateias e essas coisas todas. Quando foi à noite, o outro chegou no nosso acampamento, e achou que era pescador, então não teve mais jeito dele sair. Ele estava também já cansado. Foi honesto ao dizer: "Sabe, eu sou mesmo pesquisador de garimpo, tem cinco anos que eu pesquiso dentro dessa Terra Indígena". Ele foi relatando, e acrescentou "Eu saí, eu tenho uma picada. Uma vez eu entrei em tal canto e saí em tal canto". Listou os nomes de todos igarapés da região por onde andava. 